around the coal-pebbles, which, from their greater hardness, have left their impress in the plants; but the crystallisation of the former has a uniform parallelism with the faces of its cleavage, while the cleavage of the older coal is parallel with the sides of pebbles, which occur in all positions, sometimes in the form of a rhomboid, with its edges and corners rounded by attrition. To the east of Swansea, near Southern Down and Dunraven Castle, thcre are remarkably fine exposures of Lower Lias full of Gryphea incurva, with large ammonites and belemnites. Last year an enormous slab was dug out of the Trias rocks at Shortlands, which bears five trifid impressions in a clear series. The length of each footprint is $9 \frac{1}{4}$ inches, and it appears to have been made by "some solidly-built shortlegged creature." A little further east the Rhretic Passage Beds are laid open for a distance of more than twenty miles to Penarth Headland, where Carduum rhaticum and numerous other characteristic fossils are found. Through these strata there are many railway cuttings and no less than six passenger stations, so that this district is perhaps the best in the whole country for the study of Rhæric strata in the fields. The peninsula of Gower, west of Swansea, besides offering such scientific attractions as bone-caves, underground water-courses, raised beaches, \&c., is remarkable for the great beauty and variety of its scenery. Bold highlands and beetling cliffs alternate with heathery downs and commons, well wooded valleys through which trout streams flow, and rocky gorges, half hidden by luxuriant growths of fern. Tumuli, Druidic stones, Roman and Danish earthworks, and a round dozen Norman castles, dating for the most part from the days of William Rufus, lend additional charm to the district, which is peopled by the descendants of a colony of Flemings, who still retain many characteristic words, idioms, and customs, which the ethnologist may profitably study. The lonely granitic rocky island at the cntrance to the Bristol Channel is associated with the geology of the Barnstaple district; but it has a history all its own, and a peculiar species of rat. Ilfracombe, on the Devonshire coast, is only two hours from Swansea Pier by a fast-going steam-boat. At Pembroke Dock, on the occasion of the visit, there will be a considerable number of notable ships and corvettes of war, and the Great Eastern. Minor excursions will run through the magnificent haven of Milford, and to Tenby, while arrangements are made to take fifty persons by road to St. David's City and Cathedral, with the ruined palace and colleges of the see of Menevia, in the utmost limits of Pembrokeshire.

All these excursions are fixed for Saturday, the 28 th, and the Local Committee exact that all applications be sent in before I p.m. of the previous Thursday.

On the succeeding Thursday, September 2, the excursions, which are very numerous, will be for the most part to collieries and works. Perhaps the chief interest attaching to Swansea is its metallic industries, of which the district is a chief centre. The copper trade has flourished here for a century and a half to two centurics, but though various new processes have been tried from time to time, practically the oldest dry process, called the Welsh method, is still in use. It is affirmed that ninetenths of the copper-smelting of the kingdom is done here. The sulphurous and arsenious fumes from these works have entirely denuded the hill-sides of verdure, but it cannot be shown that they injure human health. Among the many inventions for the consumption of this smoke, are washing it with water, collecting the sulphurous acid and converting it into sulphuric acid, and the use of deposit chambers and high chimneys. These processes may be seen at Hafod, the works of Mr. H. H. Vivian, M.P. The other excursions on the same day include various large tin works, where the whole of the processes of making the iron sheets and tinning them may be seen, and the visitors will be entertained at luncheon by the Worshipful Mayor at his Cwmbwrla Tin-plate Works; to the Landore Siemens Steel Works, where steel is made in gas regenerative furnaces by the Siemens-Martin process, and hammered and rolled and tested for rails, armour-plates, ship and boiler plates, knives, needles, wire, and all other commercial purposes, and visitors will be entertained at lunch by Dr. Siemens; to the Dyffwyn Collieries at Neath, the Navigation Colliery at Quaker's Yard, the Penrhiwceiber Colliery, Mountain Ash, \&c., the most important coal winnings in the district, at each of which places visitors will be entertained. Visitors to Neath Abbey and district will take luncheon in the ruined refectory, and those to the Vale of Neath Waterfalls in the caves. At their Melyn Decorative Tin Works Messrs. Leach, Flower and Co. will show their extremely interesting processes and give a luncheon; Mr. J. T. D. Llewelyn, of Penllergare, will receive Ioo visitors at his ancient and beautifully-situated residence five miles from Swansea; and Mrs. Crawshay will entertain on this day fifty visitors at Langorse Pool, Brecon. The oyster-dredging expedition in the Bay will start from Swansea Piers, and visit the Lighthouse Rock and Battery, luncheon being served on board. The neighbouring works, which may be easily reached from the town, include the manufacture of patent fuel in the old and in a perfectly new perforated form; sulphuric acid, phosphate manures, cobalt, silver, nickel, lead, spelter, sulphate of ammonia, oxalic acid, distillation of wood, alkalies, \&c., \&c.

Applications for tickets for these excursions on Thursday, September 2, must be made not later than the forcnoon of the previous Monday.

Among the special attractions which will take place concurrently in Swansea are an agricultural show, a flower show, and especially an exhibition of local productions and processes. The exhibition of machinery will be on an extensive scale, and the greater part will be in motion. The more interesting portions of the machinery in motion and the loan exhibition of scientific instruments will be retained as an additional attraction to the second soirée.

The accommodation in the town and in the picturesque suburban watering-place of Oystermouth or The Mumbles is in every way ample, and the hospitality will be generous, but it would much facilitate the work of the Local Committec and add greatly to the satisfaction of visitors themselves if they would give timely and sufficient notice of their intention to be present on the occasion.

\section{THE HIGH PLATEAUX OF UTAH}

T NTIL a few years ago the geography of the high grounds of the western part of North America was depicted, even on the best maps, in a manner which now appears almost like a caricature of nature. So much had been said and written about the Rocky Mountains that the popular imagination was wont to picture them as a colossal, rugged, and almost impassable range, extending continuously down the backbone of the continent, and serving generally as the watershed between the Atlantic and Pacific Oceans. The progress of research, however, dissipated this delusion by showing that, instead of one continuous chain of mountains, a vast area of country, extending from the British possessions far down into the Southern States, has been upraised into elevated plains or table lands, and that these at various distances have been ridged up by lenticular mountain-chains, sometimes parallel, sometimes en échelon, and trending generally in a meridional direction. The term "Rocky Mountains" is now commonly restricted to the most easterly line of

I " Report on the Geology of the High Plateaux of Utah." With Atias. Territories. J. W. Powell in cliarge. (Washington, 1880.) 
mountains, which serves as a divide or water-parting between the Atlantic slope and the regions lying to the west. But though the traditional glories of the Rocky Mountains have thus been dimmed, and though the most enthusiastic traveller through their still little-known solitudes must in fairness admit that they cannot boast among their innumerable ranges, hitherto visited and described, one which for variety and majesty of outline can be named with the Bernese Obcrland, yet this merely nominal degradation is more than compensated by the discovery that these western territories contain a type of high ground to which there is probably no adequate parallel elsewhere on the face of the globe-a type so strange and overwhelming in its first aspect, so weird and almost incredible in its history, that the ordinary language of scenic description fails to convey the impression which the overawed beholder wishes to produce, and he finds himself obliged to borrow a new vocabulary, yet even with its aid is conscious that his narrative, exaggerated as it may seem, falls infinitely short of doing justice to the marvels he has seen.

To the portion of this region which, bounded by the Colorado Park Mountains on the east and by the ranges which border the Great Basin on the west, stretches from Southern Wyoming far into New Mexico and Arizona, the name of the Plateau Country has been given. It is drained mainly by the Colorado River and its tributaries. Its surface at lower levels than 7,000 feet above the sca is a blazing desert, bright with strange mineral coloursglaring red, livid purple, verdigris green, toned white, and ashy grey. On these plains hardly any vegetation grows. Not a solitary tree, save here and there a gnarled cedar, affords a scanty shade, and little but stunted sagebrush or prickly cactus in scattered tufts varies the eternal monotony of the burning soil. It is a region of perpetual drought, for the springs are believed not to arerage one in a thousand square miles. Yet the land is traversed by a network of rivers, which, however, wind along in profound chasms, to be crossed only by the birds of the air. So deep and sombre are many of these gorges (that of the Colorado being in some places more than a mile deep), that the very sound of their running waters never reaches the level of the plateau above. Only a dim daylight reaches the bottom, and the stars are said to be visible in ccrtain narrow gorges at midday. But where the level of the plateaux rises high enough to condense some of the moisture which the air-currents carry across them the verdureless aspect of the lower plains is replaced by luxuriant forests and open glades carpeted with rich grass and wild flowers. So colossal, however, are the table-lands that some of them slope gradually out of the range of tree-growth to a height of from $11, \infty 00$ to $12, \infty, 0$ fcet above the sea, and almost lic within the limit of perpetual snow.

So far as yet known, the Platcau country reaches the fullest development of its extraordinary features in the southern portions of the Territory of Utah. This region was partially explored by Prof. Powell during his surveys from 1869 to 1874 , and by the parties under Capt. Wheeler, especially by Mr. Howell and Mr. Gilbert, whose published reports form a valuable portion of the third volume of the "Geographical and Geological Explora. tions west of the One Hundredth Meridian," conducted by Capt. Wheeler. In $1875 \mathrm{Mr}$. Powell secured the services of Capt. Dutton for the investigation of a large volcanic tract among the Utah Plateaux as part of the survey under his direction. Capt. Dutton spent the seasons of 1875,1876 , and 1877 at the task assigned to him. We have now the result of this labour in the handsome quarto volume and beautiful atlas which have just appeared. This publication is undoubtedly one of the very best of the many admirable contributions to geology which have recently been madc by the official surveys of the United States. With the aid of the letterpress, maps, and sections any geological reader can follow and realise to himself the almost incredible magnificence, as well as simplicity, of the structure of these high Platcaux.

The geology of the arca may be briefly described as presenting a succession of nearly horizontal sedimentary formations from the upper Carboniferous up to the Eocene lacustrine deposits of the West, thrown into a succession of broad folds, cut into segments by a series of important faults, and overlaid towards the north by vast sheets of volcanic ejections, the whole of the rocks, aqueous and igneous, having peen carved into valleys, gorges, escarpments, outliers, and isolated plateaux of the most imposing magnitude.

From the Carboniferous up to the top of the Cretaceaus series there does not appear to be any general physical break in the continuity of the stratification. The Carboniferous rocks arc only partially exposed, but their overlying beds -the singular deep purple, chocolate, slate, and brownishred Shinarump group-attain a greater development, exbibiting their peculiar regularity of sedimentation and their sculptured terraces and outliers. These characteristic strata have been classed as Permian or Lower Triassic, but the rescarches of last ycar have, we believe, brought to light fossils which point unmistakably to their Permian age. An occasional want of conformability is observed between them and the overlying Trias, but as a rule the latter follow without discordance, and rise into the succession of bright red and orange sandstones and shales which constitute the great cliff-forming series throughout the Platcau country. A geologist accustomed to the scenery of the "New Red" plains of Central England may find it hard to believe that the Trias of Western America forms ranges of vermilion-coloured cliffs 1,000 or 1,500 feet high, projecting in vast promontories, retiring into deep bays, and stretching with the same brightness of colour and the same regularity of front for hundreds of miles. No very satisfactory line has yet been drawn between the Trias and the Jura. The latter series consists in the Plateau country of two members, the lower being a massive grey or white sandstone of great thickness, the upper a series of calcareous and gypsiferous shales from 200 to 400 fect thick. This sandstone, according to Capt. Dutton, was laid down over an area which cannot fall much short of 35,000 square miles, with an average thickness of more than $1, \infty 00$ feet. Yet so persistent were the conditions of its deposit that from bottom to top, sometimes through a depth of nearly 2,000 feet, it everywhere consists of intricately false-bedded sandstone without layers or partings of shaly or other heterogeneous matter. From the Upper Jurassic calcarcous; beds distinctive fossils have becn obtained.

'The Cretaceous system presents here the usual massive devclopment of sandstones and shales which form so prominent a feature in the geology of the West. The Lower Cretaccous Dakotah group is recognised by its lithological resemblance to the corresponding beds in Colorado and elsewhere, and by the occurrence of species of Ostrea, Gryphaca, Exogyra, Plicatula, \&c. The overlying shales are identified with the Laramic group, which the author places as Upper Cretaceous. The whole of the Cretaceous series is more or less lignitiferous; a considerable number of workable coal-seams in it being already known. At the close of the deposition of the Laramie group the first important break in the succession of the rocks occurs. Extensive disturbance took place along the old Mesozoic shorc-line which now bounds the Great Basin on the east, and this was accompanied and followed by such enormous denudation that the Cretaceous series, several thousand feet in thickness, was entirely removed and the oldest Tertiary strata accumulated on the exposed surface of Jurassic beds. Yet so local were these movements that in adjacent tracts the whole Cretaceous serics of the region is present, and 
appears to be followed without interruption by a conformable suite of Eocene strata.

The geographical changes that closed the Cretaceous period in the West were among the most important in the evolution of the American continent. Over many thousand square miles the floor of the sea was raised into land which has never since been again submerged. The lacustrine conditions which began in Cretaceous times now received a far greater development. The waters of the ocean, inclosed into inland seas, from brackish became fresh, and one or more lakes, of perhaps even greater dimensions than those of Eastern America, stretched between the heights of the Great Basin and the Rocky Mountains for as yet an unknown distance to the south. The history of these lakes has been studied by Hayden, King, Powell, and other geologists, and their marvellously rich ichthyic, reptilian, and mammalian fauna has been described by Leidy, Marsh, and Cope. Much remains to be done before the history can be regarded as even approximately filled in. In the meanwhile it is ccrtain that this lacustrine area was undergoing slow subsidence during Eocene time, that sediment was being continually washed into it from adjoining mountains, that eventually 5,000 feet or more of strata were laid down over its site, and that the area of fresh water progressively diminished.

A new chapter in this eventful history is revealed by Capt. Dutton. He tells how in Southern Utah the lake, even as far back as the time of the Middle Eocene, was the theatre of volcanic discharges, and how these, after vast intervals of quiescence and almost incredible denudation, have been from time to time renewed down even to a period so recent that it can hardly be believed to date so far back as the days of Cortez and the Spanish Conquest. He shows that this volcanic district discloses a remarkable variety of phenomena, nearly every form of eruption being exhibited, and every great group of volcanic rocks being represented in it. The earliest volcanic rocks are tuffs, which he regards as probably derived in chief measure from the degradation of older lavas and the deposit of the resulting sediment on the floor of the lake. The next phase of volcanic activity was marked by the outpouring of masses of propylite and hornblendeandesite, and was succeeded by the third and grandest of all, when floods of trachytes and rhyolites, alternating with augitic andesites and dolerites, rolled far and wide over the plateaux. The author is doubtful whether these extravasations proceeded from Ætna-like summits or craters, and is rather inclined to look upon the larger deluges as having issued from local fissures. Certainly if any true lofty volcanic cones existed, all external trace of them has been completely effaced by denudation. The closing event in this long volcanic period, if indeed the record can be properly regarded as even yet closed, consisted in the emission of abundant streams of lava round the larger areas of previous activity. Capt. Dutton notices some remarkable examples of a feature which occurs on a much smaller scaie in the volcanic region of the Rhinc and Moselle. The basalt cones and craters whence the streams have emanated seldom appear at the base of the great cliffs or at the bottoms of the deep cañons. They are often crowded together near the crests of the terrace walls, or the lava has broken out from the face of a wall. They commonly lie near lines of fault, yet appear almost always on the uplifted instead of the depressed side of the dislocation. "The least common place for a basaltic crater is at the base of a cliff." Among the volcanic masses special attention is given to the enormous accumulations of conglomerate and tuff, which cover nearly 2,00o square miles of area, and range from a few hundred feet to nearly 2,500 feet in thickness. These vast piles of coarse detritus the author attributes to the atmospheric disintegration of previously erupted lavas, and he describes in detail the process by which similar conglomerates are at the present moment being formed by frost, rain, and mountain-torrents. The highly important observation was made by him among the older tuffs, that in some places they have been so metamorphosed that the product of alteration is a rock possessing all the ordinary characters of a lava.

The chronological sequence of volcanic rocks among the Plateaux of Utah has been recognised as obeying generally the order enunciated by Richthofen. Capt. Dutton, starting from this observed scquence, devotes two long chapters to theoretical discussion-one on the classification, the other on the origin of volcanic rocks. To his work in the field he has added careful labour indoors, especially studying the microscopical and chemical characters of volcanic rocks. No one can read his pages without recognising their suggestiveness, even though the conclusions reached in them may sometimes appear doubtfully valid. His remarks upon the texture of volcanic rocks (pp. 9I-99) offer an excellent sample of his critical treatment. Pointing out how different may be the texture assumed by the same original magma according to whether the mass has cooled and consolidated at the surface or beneath it, he is disposed to regard the intrusive condition as a kind of intermediate stage between volcanic rocks which have issued above ground and non-ertuptive masses which have remained inactive deep beneath it, and he regards the porphyritic texture as especially characteristic of this "qualified eruption." This generalisation is only partially supported by the volcanic history of Britain. Among our older Palæozoic rocks, indeed, the intrusive or injected masses very generally possess the porphyritic structure. But from the time of the Lower Old Red Sandstone onwards to the Miocene volcanic period inclusive, the intrusive sheets are for the most part non-porphyritic, while the porphyritic structure is found among the superficial lavas. The classification our author proposes is as follows :-

\section{ACID SERIES-Group I. Rhyolites.}

Sub-group I. Nevadite or granitoid rhyolite.

2. Liparite or porphyritic rhyolite.

3. Rhyolite proper, or hyaline rhyolite.

SUB·ACID SERIES-Group II. TRACHYTES.

Sub-group A. Sanidine Trachytes.

I. Granitoid Trachyte.

2. Porphyritic Trachyte.

3. Argilloid Trachyte.

4. Hyaline Trachyte.

Sub-group B. Hornblendic Trachytes.

5. Hornblendic Trachyte.

6. Augitic Trachyte.

7. Phonolite.

8. Trachytic Obsidian.

SUB-BASIC SERIES-PROPYLITE AND ANDESITE.

Sub-group I. IIornblendic Propylite.

2. Augitic Propylite (?).

3. Quartz-Propylite.

4. Hornblendic Andesite.

5. Augitic Andesite.

6. Dacite or Quartz-andesite.

BASIC SERIES-BASALTS.

Sub-group r. Dolerite.

2. Nepheline-dolerite.

3. Basalt.

4. Leucite-basalt.

5. Nepheline-basalt.

6. Tachylite.

The fifth chapter is entitled "Speculations concerning the Causes of Volcanic Action." The author propounds a very ingenious trial hypothesis, by which he believes the sequence of volcanic phenomena throughout at least the Rocky Mountain region may be explained. $\mathrm{He}$ asstimes that volcanic phenomena are brought about by a 
local increase of temperature within certain subterranean horizons. But, as he himself admits, this way of putting the case brings us no nearer to what may be the ultimate cause of such a local increase of temperature. He seeks to prove that all the phenomena of volcanic action point to local excitation, and that the observed order of appearance of lavas is what on this view might theoretically be anticipated. It would be beyond the necessary limits of this article to follow him into the details of his argument. But one or two points may be briefly referred to. $\mathrm{He}$ regards lavas as mainly derived not from primeval subterranean magmas, but rather from the fusion of such rocks as the crystalline schists and sedimentary formations. In the mechanics of eruptions he believes that the outpouring of lava does not arise from the expansion of vapours absorbed within the molten magma, but is merely a hydrostatic problem of the simplest order-the lava being forced out by the weight of the rocks overlying its subterranean reservoirs.

According to this hypothesis two preliminary conditions are requisite for an eruption of lava-the rocks must be fused, and their density in the molten state must be less than that of the overlying rocks. The author regards the observed order of appearance of the lavas to be determined by their relative density and fusibility, the more siliceous requiring a higher temperature to fuse them, and the more basic, though less refractory, demanding a higher temperature to give them such a diminution of density as will permit them to be erupted. At an early stage of eruption he holds that the acid rocks may be light enough to be ejected, but are not yet melted, while the basic rocks may be melted but must await further expansion by access of heat before they are capable of being poured forth. Hence some intermediate rock will be selected as the first to issue, and this rock the author believes to be propylite. A further increase of temperature produces hornblendic andesite and trachyte, and so on to the rhyolites, and finally the basalts. All rocks more basic than propylite are stated to present evidence of superfusion, these rocks, according to the theory, being those which possess so high a density as to demand a much greater accession of heat than that required for mere fusion, in order that they may become lighter than the overlying crust, and thus be erupted. Basalt in particular is cited as an example of a superfused rock

The author tacitly assumes that the density of a lava at the time of its outflow is necessarily less than that of the rocks through which it ascends, otherwise it could not be erupted. It is a pity that no experimental demonstration of this assertion was given, for it forms so fundamental a postulate in the hypothesis. But even on the supposition that the lava is forced out by the descent of heavier overlying rock, what ought to be found as proof of this action? Ought we not to meet with abundant evidence of subsidence at volcanic foci? Every mass of lava derived from the local fusion of rocks at no great depth beneath the surface and driven out by the weight of rock overlying it, should have an accompanying and proportionate subsidence of the crust over the site of its source. Occasional proofs of collapse at volcanoes have long been known indeed, but admit of other explanation, such as "evisceration," to use Mr. Mallet's phrase. Instead of subsidence, the emission of volcanic material has generally been accompanied with upheaval. Capt. Dutton's own magnificent Plateaux of Utah should furnish copious proofs of a sinking or sagging of the nearly horizontal strata round the eruptive vents. But there is no trace of any structure of this kind in his instructive and carefully-drawn sections.

Again, the alleged superfusion of the basic rocks can hardly be admitted upon the evidence here brought forward in its support. The fact that thin streams of basalt have had a greater liquidity and have retained it for much greater distances than the acid lavas, has long been recognised. But as Reyer has recently suggested, it is capable of a different interpretation from that of superfusion. The author appeals also to the microscopic structure of basalt as favouring his view of former intense ignition. He cites, for example, the presence of glass particles, the absence of water-cavities, the isotropic base, the compactness and vitreous structure of this rock. But are not these characters present in far more striking development among the vitreous acid rocks, which he supposes to have had a temperature little more than sufficient for fusion? The exceptions which the author candidly admits to occur in the normal succession of lavas-basalts, for example, appearing before rhyolites, or quartz propylite and quartz-andesite simultaneously with the hornblendic members of their respective groups-seem fatal to the hypothesis.

From another point of view the idea that the order of emission of lavas has been determined in the way supposed presents great difficulties. The author affirms that "we must at least admit that the source of lavas is among segregated masses of heterogenous materials," and he supposes that "this arrangement would be well satisfied by a succession of metamorphic strata [gneiss, hornblendic and augitic schist] resting upon a supposed primitive crust or magma having a constitution approximating that of the basaltic group of rocks." But every known mass of metamorphic strata presents endless interstratifications of very various materials. By what process of selection are the elements of these diverse rocks grouped successively into definite volcanic compounds? How is it that out of the simmering subterranean broth just so much silica and alumina as are needed for one type are ladled out at one time, while a careful hand is kept on the lime, alkalies and iron-oxides, only the right proportions being dealt forth for each lava?

The remarkable persistence of type among the different species of lava all over the world has long been recognised. It is not easy to see how this persistence should exist, nor why there should not be far more varieties of lava and transitional grades between the varieties if they are due to the local melting up of various masses of heterogeneous materials within the crust.

The volume is illustrated by a series of heliotype plates, from photographs taken in the course of the survey, representing some of the more remarkable external forms assumed by the sedimentary and volcanic rocks. The Atlas contains a valuable series of topographical and geological maps. Among these a relief-map of the Plateaux, on the scale of five miles to an inch, is specially instructive. There are likewise two plates of sections, which bring before the eye in a clear and concise form the structural details of the region. In point of execution the plates of the atlas are altogether admirable. In his preface Capt. Dutton states that he undertook the task of exploration assigned to him with considerable diffidence in his ability to accomplish it. He must be congratulated on having achieved a signal succers. His work bears everywhere marks of the most conscientious and painstaking industry, great acuteness of observation, and not a little literary skill in the marshalling and presentation of the facts observed. Let us hope that the arrangement by which he was enabled to exchange the routine duties of an army officer for geolological field-work may be prolonged, and that in further prosecution of his explorations in the West he may live to issue other volumes as interesting and valuable as that which is noticed here.

ARCH. GEIKIE

\section{TWO NEW PLANETARY NEBULAE}

A PLANETARY nebula in R.A. I $8 \mathrm{~h} .25^{\circ} \mathrm{m}$. and A Dec. - $25^{\circ} 13^{\prime}$ was discovered at the Harvard College Observatory on the evening of July 13. A second 